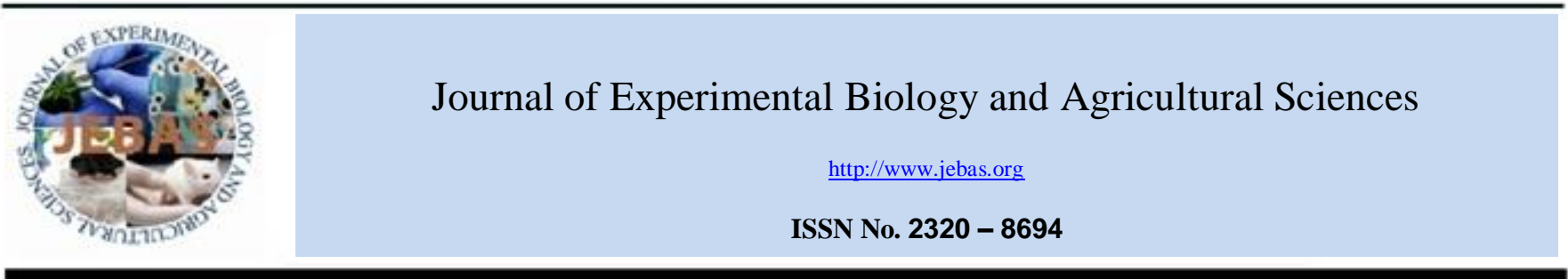

\title{
GENETIC VARIABILITY FOR GRAIN QUALITY TRAITS IN INDIGENOUS RICE LANDRACES OF CHHATTISGARH, INDIA
}

\author{
Parmeshwar K. Sahu ${ }^{1}$, Deepak Sharma ${ }^{1 *}$, Suvendu Mondal ${ }^{2}$, Vikash Kumar ${ }^{2}$, Satyapal Singh ${ }^{1}$, \\ Samarth Baghel ${ }^{1}$, Ashish Tiwari ${ }^{1}$, Gautam Vishwakarma ${ }^{2}$, B.K. Das ${ }^{2}$
}

${ }^{1}$ Department of Genetics and Plant Breeding, Indira Gandhi KrishiVishwavidyalaya, Raipur-492012 (CG), India

${ }^{2}$ Nuclear Agriculture and Biotechnology Division, Bhabha Atomic Research Centre, Mumbai- 400085, India

Received - June 23, 2017; Revision - July 19, 2017; Accepted - September 03, 2017

Available Online - September 10, 2017

DOI: http://dx.doi.org/10.18006/2017.5(4).439.455

\section{KEYWORDS \\ Rice \\ Landraces \\ Grain quality \\ Genetic variability \\ Amylose content}

\section{ABSTRACT}

The investigation was carried out to estimate the components of genetic variability and associated statistical parameters for grain quality traits of 215 indigenous rice landraces of Chhattisgarh, India. Substantial genetic variability among the all genotypes was observed for the characteristics under study. All the genotypes were showed highly significant differences for all the studied grain quality traits. Coefficient of variation ranges from $8.61 \%$ for hulling percentage to $45.01 \%$ for alkali spreading value. Negligible difference between genotypic coefficient of variation and phenotypic coefficient of variation was observed for all the traits. High heritability with high genetic advance as percent mean was observed for all the grain quality traits except for hulling percent and milling percent. These results indicated that direct selection based on phenotypic performance could be rewarding for all quality traits because they are less influenced by environment and mostly governed by additive gene action. It has been observed that sixty nine genotypes had short slender type grain characteristics whereas; forty seven genotypes have short bold type grains. Thirty genotypes showed more than $80 \%$ hulling percent, fifty six genotypes showed more than $70 \%$ milling percent and fourteen genotypes showed more than $65 \%$
* Corresponding author

E-mail: deepakhybridrice@ gmail.com (Deepak Sharma)

Peer review under responsibility of Journal of Experimental Biology and Agricultural Sciences.

Production and Hosting by Horizon Publisher India [HPI] (http://www.horizonpublisherindia.in/).

All rights reserved.
All the article published by Journal of Experimental Biology and Agricultural Sciences is licensed under a Creative Commons Attribution-NonCommercial 4.0 International License Based on a work at www.jebas.org.

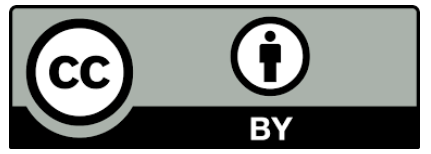


head rice recovery percent. Total sixty nine genotypes have intermediate type alkali spreading value which has $70-74^{\circ} \mathrm{C}$ gelatinization temperature and total hundred genotypes has intermediate amylose content (20-25\%). Tulsimanjari, Luchai, BaiganiDhan, Kapri, and Badshahbhog have been identified superior genotypes for all of the quality traits. Superior genotypes identified for various quality traits could be utilized for future breeding programme.

\section{Introduction}

Rice landraces, local varieties, indigenous lines play a pivotal role for food nutritional and health security besides resistance to diseases and pests and resilience to climate changes which is needed for the survival of human civilization on earth. Rice is food grain crop of global importance with special preference in Asian countries. Grain yield improvement is the prime objective of plant breeders for several decades but demand for good quality rice is also increased in current decade as living standard of people are being gradually improved (Rathi et al., 2010). Therefore, improvement of grain quality features of rice becomes the utmost objective next to yield enhancement and has become major concern in rice breeding programs to meet the consumer preference and market demand. Rice varieties having good milling parameters, good appearance quality, good cooking and eating parameters, can be considered as superior grain quality rice variety which increases the total economic value of rice. Consumer preferences for good quality rice varied from one geographical region to another (Juliano \& Perez CM, 1984; Rathi et al., 2010). In India, long grain specially Basmati varieties and fine or short slender grain varieties with intermediate amylose and alkali spreading value, intermediate gel consistency and high volume expansion of cooked rice is preferred. Whereas, low amylose and short grain is preferred in China and Japan (Hossain et al., 2009). Chhattisgarh state is popular as Rice Bowl of India, where tribal peoples grown traditional rice varieties since past hundreds of years. These varieties have special dominating character in terms of wide adoptability and tolerant to climate change. More than 23250 rice germplasm were recorded in Chhattisgarh state which showed vast diversity for specific quality traits viz. aroma, good cooking quality, grain type and shape, kernel colour etc. Short grain aromatic rice of Chhattisgarh is very popular due to its premium grain quality. Rice is consumed principally as a whole grain therefore; the texture of the whole grain is a matter of primary importance (Kumar, 1989; Hossain et al., 2009). Several studies on genetic variability parameters and descriptive statistics for grain quality traits have been previously conducted. In spite of that unexploited genetic variability is still exist in rice landraces which are of equally important in selecting the superior parents. These superior parents can give extreme heterosis and superior recombinants for better grain quality components (Karuppaiyan et al., 2013). Genetic parameters such as genotypic coefficient of variation and phenotypic coefficient of variation are the important genetical parameters for mining the amount of variability present in the germplasm. Role of environmental attributes on the expression any genotype and reliability of characters can be determined precisely by high broad sense heritability united with high genetic advance (Babu et al., 2012).

Descriptive statistical measures viz., mean, median, range, quartiles, standard deviation, standard error, skewness and kurtosis, can reveal a great deal of information about any variable of interest. Rice genetic resources are a key component to breeding programs and farmers have long played an important role, contributing to rice diversity by developing and nurturing thousands of rice varieties (Bellon et al., 1997). This vast wealth of rice germplasm including landraces and traditional varieties is a good source of important alleles to develop new rice varieties (Rabara et al., 2014)

Despite abundant genetic resources, only a small proportion of the total rice germplasm collection has been used in breeding programs. This discrepancy has narrowed the genetic base in most improved varieties and advance breeding lines (Kumbhar et al., 2015). Hence, appropriate conservation of landraces and broadening the gene pool of rice varieties has become necessary for breeding rice varieties with high yields and superior grain qualities in India. Germplasm/land races constitute the foundation for genetic improvement of crops. Therefore, the present experiment was conducted to assess nature and magnitude of variability parameters and descriptive statistics for grain quality traits in 215 indigenous rice landraces of Chhattisgarh, India.

\section{Materials and Methods}

\subsection{Plant materials}

The experimental material comprises total of 215 genotypes including 213 traditional landraces and two local varieties (Mahamaya and Rajeshwari) of rice of Chhattisgarh, India (Table 1). A total of 600 rice landraces and local varieties were collected from different parts of Chhattisgarh and were grown at research field, IGKV, Raipur during Kharif 2015 by following the 
Table 1 List of rice genotypes used for the study

\begin{tabular}{|c|c|c|c|c|c|c|c|}
\hline S. No. & Name & S. No. & Name & S. No. & Name & S. No & Name \\
\hline 1 & Luchai & 31 & Chhindmauri & 61 & Badshabhog-2 & 91 & NariyalJhoba \\
\hline 2 & Sonagathi & 32 & Karhani & 62 & Lajini Super & 92 & Sindursal \\
\hline 3 & Kherkakuchi & 33 & Sihar & 63 & Gangabaru & 93 & Chhindmauri \\
\hline 4 & Dadbanko & 34 & JhimiprasSamlayi & 64 & GudkamalDhan & 94 & Sugandha \\
\hline 5 & Danighoda & 35 & Nandel & 65 & TulsiManjari & 95 & Dandrice \\
\hline 6 & Anjani & 36 & Kapri & 66 & Kanakbhog & 96 & BansveeraDhan \\
\hline 7 & Bathrash & 37 & Bhusi & 67 & DRRH-3 & 97 & Jhingapuchhi \\
\hline 8 & Saraitoliha & 38 & DhauraMundariya & 68 & Mahamaya & 98 & BeedelaDhan \\
\hline 9 & Jonyaphool & 39 & Gangachur & 69 & Rajeshwari & 99 & Sonagathi-2 \\
\hline 10 & Pratiksha & 40 & Karhani & 70 & HR 14-1 Heera & 100 & PhalodDhan \\
\hline 11 & Bhadvel & 41 & Byalo & 71 & MatkoDhan & 101 & LalmaDhan \\
\hline 12 & Ranikajal & 42 & Bhusu & 72 & NimaliyaBanki & 102 & BaiganiDhan \\
\hline 13 & Bhajna & 43 & Safri-2 & 73 & Jonyaphool & 103 & MaranDhan \\
\hline 14 & Ratajhinga & 44 & Sanchorma & 74 & Kadamphool & 104 & LoktiMusi \\
\hline 15 & Pataniyajhuli & 45 & SatraSafri & 75 & Indjopa & 105 & AsamChudi \\
\hline 16 & Laxmibhog & 46 & Barhani & 76 & Ramigauri & 106 & Jana Dhan \\
\hline 17 & Sawani & 47 & Kanakbans & 77 & Brown Rice-1 & 107 & RelaDhan \\
\hline 18 & Jhilli & 48 & Jhimipras-2 & 78 & Arokhutu & 108 & Jhunuprash \\
\hline 19 & Tulsimongra & 49 & Dhaniyaphool & 79 & Brown Rice-2 & 109 & OdhaDhanBanarsi \\
\hline 20 & DhauraMundariya & 50 & Lalbarhasal & 80 & Dubraj & 110 & B.D. Safri \\
\hline 21 & Jhimipras & 51 & Alsenga & 81 & HathiPanjra & 111 & Lochai \\
\hline 22 & PangudiGoindi & 52 & Barhasal-2 & 82 & Modipeera & 112 & GadurSela \\
\hline 23 & Safri & 53 & RuchiDhan & 83 & Petgadi & 113 & KareniDhan \\
\hline 24 & Barhasal & 54 & Rudra & 84 & Ramlaxman & 114 & PivriLochai \\
\hline 25 & Dubraj & 55 & Bhunduluchai & 85 & Raja Banga & 115 & $\begin{array}{lr}\text { Govardhan } & \text { Kali } \\
\text { Kamod 2 } & \\
\end{array}$ \\
\hline 26 & Agyasal & 56 & Barhasal-3 & 86 & Kari Gilash & 116 & Loindi \\
\hline 27 & Jauphool & 57 & Khetganga & 87 & Muni Bhog & 117 & Santio \\
\hline 28 & Kalajeera & 58 & Bashabhog & 88 & SuaPankhi & 118 & Parra Dhan \\
\hline 29 & Byalo & 59 & Tulsibhog & 89 & Mala Gauri & 119 & Godadani \\
\hline 30 & Badshabhog & 60 & Nariyalphool & 90 & DokraDokri & 120 & Ramshri \\
\hline
\end{tabular}




\begin{tabular}{|c|c|c|c|c|c|c|c|}
\hline S. No. & Name & S. No. & Name & S. No. & Name & S. No. & Name \\
\hline 121 & Danwar & 135 & Kumhdayin & 149 & BaktiChudi & 163 & Kalinga \\
\hline 122 & ChatiyaNakhi & 136 & BhejrimaiDhan & 150 & JhilliSafri & 164 & Bhusu \\
\hline 123 & BhathaMasri & 137 & RatanChudi & 151 & Nanded & 165 & Kabeli \\
\hline 124 & Kanchan & 138 & Panwar & 152 & TuriyaKhudig & 166 & Gatuvan \\
\hline 125 & BaigaSeeng & 139 & Chhindmauri & 153 & Antarved & 167 & Baikoni \\
\hline 126 & Mota Safri-2 & 140 & Rani Parewa & 154 & Rang Chudi & 168 & ChinniParas \\
\hline 127 & MohlaiBanko & 141 & Ramlichonch & 155 & MotaChudi & 169 & Jalsinga \\
\hline 128 & SutaiDhan & 142 & Mejhri & 156 & B.D. Safri-2 & 170 & Agni Fag \\
\hline 129 & Haripanti & 143 & Bodibaja & 157 & KharikhaKuchi & 171 & Lalapana \\
\hline 130 & Bhujnin & 144 & Jela & 158 & MemriKhedi & 172 & BahalBinjo \\
\hline 131 & Manki & 145 & $\begin{array}{l}\text { Badshabhog Selection- } \\
1\end{array}$ & 159 & Ankapalli & 173 & Kari Grass \\
\hline 132 & Sadachar & 146 & Kari Alcha & 160 & Samarlengda & 174 & Asam Chudi-2 \\
\hline 133 & Mahabaikoni & 147 & DeshiSurmatiya & 161 & Mayath & 175 & Tulsi Mala \\
\hline 134 & Khajoor & 148 & Anjaniya & 162 & MotaSafri & 176 & Surmatiya \\
\hline
\end{tabular}

Note: Source of all the collected landraces is IGKV, Raipur (CG), India augmented design. A core set of 215 rice landraces was constructed by selecting superior genotypes based on their grain yield and attributing traits from these 600 genotypes. All 215 landraces were cleaned properly, dried in hot air oven up to 12 $14 \%$ moisture content and kept at room temperature for four months then used for grain quality parameter estimation at R.H. Richharia Rice Research Laboratory, Department of Genetics and Plant Breeding, IGKV, Raipur (CG), India. In this investigation, grain quality parameters of each rice samples were analysed in duplicates.

\subsection{Physical parameters of rice grains:}

All the standard protocol according to Indian Institute of Rice Research, Hyderabad, India (formerly, Directorate of Rice Research) was followed for estimating the grain quality parameters (DRR, 2014).

\subsubsection{Brown rice length and breadth $(\mathrm{L} / \mathrm{B})$ ratio}

Brown rice length and breadth of 10 random samples of whole rice grains from each genotype were measured manually by using millimetre scale and graph. Average length and breadth of 10 samples were used for $\mathrm{L} / \mathrm{B}$ ratio calculation and further analysis.

\subsubsection{Brown rice recovery percent (hulling percent)}

About 100 gram of rough rice samples were hulled by a single pass through a standard rubber roll huller (Satake Engineering Co. Ltd. Tokyo, Japan) to produce brown rice (decorticated rice). The brown rice was then weighed and used for calculation of hulling percentage based on initial weight of rough rice as; hulling percent $=$ (weight of hulled rice/ weight of rough rice) $\mathrm{X} 100$ (DRR, 2014).

\subsubsection{Milled rice recovery percent (milling percent)}

Hulled brown rice was then used for milling up to 5\% by using a McGill No. 2 miller (Rapsilver Supply Co. Inc., Brookshire, TX). The generated milled rice was weighed and used for milling percent calculation based on initial weight of rough rice as; milling percent $=($ weight of milled rice/ weight of rough rice $)$ X100 (DRR, 2014).

\subsubsection{Head rice recovery percent (HRR percent)}

Milled rice kernels were separated into head rice and broken kernel fractions with different sized separator/ sieves. Full kernel 
and $3 / 4$ size kernels were considered as head rice and weighed for calculating HRR percentage. Head rice recovery percentage was calculated as; head rice recovery percent $=($ weight of full kernel and 3/4 sized kernel/ weight of rough rice) X 100 (DRR, 2014).

\subsection{Grain physico-chemical and cooking parameters}

\subsubsection{Elongation Ratio}

Elongation ratio of cooked kernels was determined by dividing the length of cooked kernel to length of uncooked kernel.

\subsubsection{Alkali Spreading Value and Gelatinization temperature (GT)}

Alkali Spreading Value and gelatinization temperature was assessed using standard alkali digestion and spreading scores (Little et al., 1958). Six whole grains from each of the genotypes were placed in plastic Petridish containing $10 \mathrm{ml} 1.7 \% \mathrm{KOH}$. The arrangements of grains were in such a way that they were not in contact with each other. All the petri dishes were properly covered and incubated at $30{ }^{\circ} \mathrm{C}$ for 23 hours. Scoring was based on visual appearance and disintegration of all the six endosperm of each genotype.

\subsubsection{Gel consistency (GC)}

Polished rice of each genotype was powdered by using mortar and pestle followed by sieved with $1 \mathrm{~mm}$ sieve. In long test tube $(2 \times 19.5 \mathrm{~cm}), 100 \mathrm{mg}$ of rice flour was taken followed by adding of $0.2 \mathrm{ml}$ of ethanol containing $0.25 \%$ thymol blue. Thereafter, $2.0 \mathrm{ml}$ of $2.8 \mathrm{~g} \mathrm{KOH}$ in $250 \mathrm{ml}$ distilled water was added into each tube and mixed properly by using vortexer. All the samples were kept in hot water bath for 8 min then cooled for 5 minutes. All the samples were vortexed again and kept in ice bath for $20 \mathrm{~min}$. Later on, all the tubes were taken out and laid horizontally on laminated graph paper for one hour to take the measurement (DRR, 2014).

\subsubsection{Amylose content (AC)}

Amylose content of each landrace was estimated by following the method of Juliano (1971). 100mg rice flour was taken into volumetric flask and added $1 \mathrm{ml}$ ethanol (95\%) with $9 \mathrm{ml}$ of sodium hydroxide $(1 \mathrm{~N})$. The samples were kept on a boiling water bath followed by cooling for 10 minutes at room temperature. Final volume of $100 \mathrm{ml}$ was made by adding distil water. Thereafter, $5 \mathrm{ml}$ solution was pipetted out from $100 \mathrm{ml}$ stock solution and added $1 \mathrm{ml}$ of acetic acid $(1 \mathrm{~N})$ and $2 \mathrm{ml}$ of freshly prepared iodine solution. Solutions were shaken properly and kept at dark place for 20 minutes and determine the absorbance at 620 $\mathrm{nm}$ using a UV-Vis spectrophotometer (Jasco, Cambridge, UK).

\subsection{Statistical analysis:}

Descriptive statistics for all the traits and histogram were made by using XLSTAT v18.07. Analysis of variance (One way ANOVA) was calculated by using OPSTAT software following the suggested formula of Panse \& Sukhatme (1967). Method suggested by Burton (1952) was followed for calculation of genotypic coefficient of variation (GCV) and phenotypic coefficient of variation (PCV). Broad sense heritability $\left(\mathrm{h}^{2}\right)$ was calculated as per method suggested by Hanson et al. (1956). Similarly, method suggested by Johnson et al. (1955) was used for the calculation of genetic advance (GA). GCV, PCV, heritability and genetic advance were analyzed manually by MS-Excel-2007 by following the above mentioned methods.

\section{Results and Discussion}

\subsection{Analysis of Variance (ANOVA)}

The analysis of variance (ANOVA) revealed the presence of highly significant differences amongall rice landraces for all the grain quality traits (Table 2). This indicates the existence of ample

Table 2 Analysis of Variance (ANOVA) for grain quality traits in indigenous rice landraces

\begin{tabular}{|c|c|c|c|c|c|c|c|c|c|c|c|c|c|c|c|c|c|}
\hline \multirow{2}{*}{$\begin{array}{l}\text { Source of } \\
\text { variation }\end{array}$} & \multirow{2}{*}{ Df } & \multicolumn{16}{|c|}{ Mean sum of squares } \\
\hline & & 1 & 2 & 3 & 4 & 5 & 6 & 7 & 8 & 9 & 10 & 11 & 12 & 13 & 14 & 15 & 16 \\
\hline Treatment & 214 & $1.11^{* * *}$ & $0.18^{*}$ & $0.42 * *$ & $0.75^{* * *}$ & $0.16^{* * *}$ & $0.35^{* * *}$ & $2.25^{* * *}$ & $0.59 * *$ & $0.38 * *$ & $0.07^{* * *}$ & $82.25^{* *}$ & $73.87 * *$ & $75.31 * *$ & $6.68 * *$ & $545.95^{* *}$ & $32.44 * *$ \\
\hline Error & 215 & 0.022 & 0.02 & 0.061 & 0.017 & 0.026 & 0.073 & 0.018 & 0.013 & 0.021 & 0.003 & 5.395 & 3.64 & 1.73 & 0.002 & 4.61 & 0.156 \\
\hline Total & 429 & & & & & & & & & & & & & & & & \\
\hline $\begin{array}{l}\text { Coefficient } \\
\text { variation }(9\end{array}$ & & 12.70 & 15.60 & 14.97 & 11.63 & 14.97 & 14.66 & 13.97 & 17.44 & 15.82 & 12.58 & 8.61 & 9.26 & 10.69 & 45.01 & 26.98 & 17.11 \\
\hline SEd & & 0.15 & 0.14 & 0.25 & 0.13 & 0.16 & 0.27 & 0.13 & 0.11 & 0.14 & 0.05 & 2.32 & 1.91 & 1.32 & 0.04 & 2.15 & 0.39 \\
\hline CD at $1 \%$ & & 0.39 & 0.37 & 0.64 & 0.34 & 0.42 & 0.70 & 0.35 & 0.30 & 0.38 & 0.14 & 6.04 & 4.96 & 3.42 & 0.12 & 5.58 & 1.03 \\
\hline $\begin{array}{l}\text { 1. Brown r } \\
\text { 2. Brown r } \\
\text { 3. Brown }\end{array}$ & $\begin{array}{l}\text { ice } \mathrm{Le} \\
\text { ice } \mathrm{Br} \\
\text { ice } \mathrm{L}\end{array}$ & $\begin{array}{l}\text { igth } \\
\text { dth } \\
3 \text { ratio }\end{array}$ & & $\begin{array}{l}\text { Kernel } r \\
\text { Kernel } r \\
\text { Kernel } r\end{array}$ & $\begin{array}{l}\text { ce Lengt } \\
\text { ce Bread } \\
\text { ce L/B r }\end{array}$ & & $\begin{array}{l}\text { 7. K } \\
\text { 8. K } \\
\text { 9. K }\end{array}$ & $\begin{array}{l}\text { ernel leng } \\
\text { ernel brea } \\
\text { ernel L/B }\end{array}$ & $\begin{array}{l}\text { th after c } \\
\text { dth after } \\
\text { ratio afte }\end{array}$ & $\begin{array}{l}\text { ooking } \\
\text { cooking } \\
\text { r cooking }\end{array}$ & $\begin{array}{l}\text { 10. El } \\
11 . \mathrm{H} \\
12 . \mathrm{M}\end{array}$ & $\begin{array}{l}\text { ongation } \mathrm{R} \\
\text { alling \% } \\
\text { illing \% }\end{array}$ & & $\begin{array}{l}13 . \\
14 . \\
15 . \\
16 .\end{array}$ & $\begin{array}{l}\text { HRR\% } \\
\text { ASV/GT } \\
\text { GC (mm } \\
\text { Amylose }\end{array}$ & $\begin{array}{l}\Gamma \\
\text { a) } \\
\text { Content }\end{array}$ & \\
\hline
\end{tabular}


amount of variability among rice landraces for studied traits. Coefficient of variation is simply a measure of dispersion of the variable. In present investigation, CV ranges from $8.61 \%$ for hulling percentage to $45.01 \%$ for alkali spreading value. Coefficient of variation was observed higher for gel consistency (26.98\%) followed by kernel breadth after cooking (17.44\%) and amylose content $(17.11 \%)$. Results indicated that overall high coefficient of variation was present for all the traits under study. The presence of a wide range of variability might be due to diverse sources of the materials having high natural recombination and mutations that has accumulated over decades in these landraces. Thus, there is a good opportunity to select better parental types improving the rice grain quality traits. The results were in consonance with the finding of Dhanwani et al. (2013); Devi et al. (2015) and Devi et al. (2016).

\subsection{Genetic Variability Parameters:}

3.2.1 Genotypic coefficient of variation (GCV) and phenotypic coefficient of variation $(\mathrm{PCV})$ :

Genetic variability parameters for all the grain quality traits are given in Table 3. Results in table exhibited wide range of variation for different traits. The maximum genotypic and phenotypic variations were obtained for gel consistency (270.67 and 275.28 respectively) followed by hulling percent (38.43 and 43.82 respectively), HRR percent ( 36.79 and 38.52 respectively) and milling percent (35.12 and 38.76 respectively). The higher $\mathrm{GV}$ and $\mathrm{PV}$ values indicated that environment influence is negligible for these traits. All the grain physical parameters were showed slightly low genotypic and phenotypic variations which are the indicative of quite stable nature of these traits. Coefficients of variation studies indicated that the estimates of phenotypic coefficient of variation (PCV) were slightly higher than the corresponding genotypic coefficient of variation (GCV) estimates for all traits indicating that phenotypic variation was determined by and large by genotype with negligible influence of extraneous factors and therefore, selection for such traits on the basis of phenotype only could also be rewarding as suggested by Babu et al. (2012) and Karuppaiyan et al. (2013).

The magnitude of coefficient of variation was categorized as high (> 20\%), moderate $(10-20 \%)$ and low (< 10\%). The high phenotypic coefficient of variation (PCV) and genotypic coefficient of variation (GCV) was observed for alkali spreading value $(45.09 \%$ and $45.08 \%)$ and gel consistency $(27.16 \%$ and $26.93 \%)$ while the brown rice length $(12.85 \%$ and $12.60 \%)$, brown rice breadth (16.44\% and $14.78 \%)$, brown rice L/B ratio

Table 3 Variability parameters for grain quality traits in indigenous rice landraces

\begin{tabular}{|c|c|c|c|c|c|c|c|c|c|}
\hline S. N. & Name of Trait & $\begin{array}{l}\text { Grand } \\
\text { Mean }\end{array}$ & $\begin{array}{c}\text { Genetic } \\
\text { variance } \\
(\mathrm{Vg})\end{array}$ & $\begin{array}{l}\text { Phenotypic } \\
\text { variance } \\
\text { (Vp) }\end{array}$ & $\begin{array}{c}\text { PCV } \\
\%\end{array}$ & GCV\% & $\begin{array}{l}\text { Heritabi } \\
\text { lity (bs) }\end{array}$ & $\begin{array}{c}\text { Genetic } \\
\text { advance } \\
\text { (GA) }\end{array}$ & $\begin{array}{c}\text { GA as } \\
\% \text { of } \\
\text { mean }\end{array}$ \\
\hline 1 & Brown rice length & 5.84 & 0.54 & 0.56 & 12.85 & 12.60 & 96.10 & 1.49 & 25.44 \\
\hline 2 & Brown rice Bredth & 1.96 & 0.08 & 0.10 & 16.44 & 14.78 & 80.77 & 0.54 & 27.36 \\
\hline 3 & Brown rice $\mathrm{L} / \mathrm{B}$ ratio & 3.03 & 0.18 & 0.24 & 16.10 & 13.89 & 74.42 & 0.75 & 24.68 \\
\hline 4 & Kernel length & 5.24 & 0.36 & 0.38 & 11.80 & 11.53 & 95.54 & 1.22 & 23.22 \\
\hline 5 & Kernel Breadth & 1.88 & 0.07 & 0.09 & 16.18 & 13.72 & 71.89 & 0.45 & 23.97 \\
\hline 6 & Kernel L/B ratio & 2.84 & 0.14 & 0.21 & 16.23 & 13.15 & 65.65 & 0.62 & 21.95 \\
\hline 7 & Kernel length after cooking & 7.58 & 1.12 & 1.14 & 14.06 & 13.95 & 98.42 & 2.16 & 28.51 \\
\hline 8 & Kernel breadth after cooking & 2.80 & 0.29 & 0.30 & 19.69 & 19.26 & 95.73 & 1.09 & 38.83 \\
\hline 9 & Kernel L/B ratio after cooking & 2.76 & 0.18 & 0.20 & 16.31 & 15.44 & 89.66 & 0.83 & 30.12 \\
\hline 10 & Elongation Ratio & 1.45 & 0.03 & 0.04 & 12.95 & 12.39 & 91.55 & 0.36 & 24.42 \\
\hline 11 & Hulling $\%$ & 74.29 & 38.43 & 43.82 & 8.91 & 8.34 & 87.69 & 11.96 & 16.10 \\
\hline 12 & Milling \% & 65.51 & 35.12 & 38.76 & 9.50 & 9.05 & 90.61 & 11.62 & 17.74 \\
\hline 13 & HRR\% & 57.25 & 36.79 & 38.52 & 10.84 & 10.59 & 95.51 & 12.21 & 21.33 \\
\hline 14 & Alkali Spreading Value & 4.05 & 3.34 & 3.34 & 45.09 & 45.08 & 99.94 & 3.76 & 92.84 \\
\hline 15 & Gel Consistency & 61.09 & 270.67 & 275.28 & 27.16 & 26.93 & 98.33 & 33.61 & 55.01 \\
\hline 16 & Amylose Content & 23.48 & 16.14 & 16.30 & 17.20 & 17.11 & 99.04 & 8.24 & 35.08 \\
\hline
\end{tabular}


(16.10\% and $13.89 \%)$, kernel length $(11.80 \%$ and $11.53 \%)$, kernel breadth $(16.18 \%$ and $13.72 \%)$, kernel $\mathrm{L} / \mathrm{B}$ ratio $(16.23 \%$ and $13.15 \%)$, kernel length after cooking (14.06\% and $13.95 \%)$, kernel breadth after cooking (19.69\% and 19.26\%), kernel L/B ratio after cooking $(16.31 \%$ and $15.44 \%)$, elongation ratio $(12.95 \%$ and $12.39 \%)$, head rice recovery percent (10.84\% and $10.59 \%)$ and amylose content (17.20\% and $17.11 \%)$ were showed intermediate PCV and GCV. Hulling percent (8.91\% and 8.34\%) and milling percent $(9.50 \%$ and $9.05 \%)$ were showed slightly lower PCV and GCV based on the scale. Higher and intermediate value of GCV gives idea for selection of trait with significant improvement. However estimation of total heritable variation based on GCV only could not give significant output (Roychowdhury \& Tah, 2011). Further, Burton \& Devane (1952) suggested that the genetic coefficient of variation together with heritability estimates gave a better picture of the extent of heritable variation. Similar results were observed by Maneerattanarungroj et al., (2015); Rathi et al., (2010); Babu et al. (2012); Chaudhary \& Singh (1994); Shivani \& Reddy (2000), Pathak \& Sharma (1996).

\subsection{2: Broad sense heritability:}

Heritability $\left(\mathrm{h}^{2}\right)$ estimates were interpreted as low $(<30 \%)$, medium $(31 \%-70 \%)$ and high $(>70 \%)$ as per the classification of Johnson et al. (1955). In the present investigation all the grain quality traits showed high heritability (broad sense) except for kernel L/B ratio (65.65\%) which showed moderate heritability. Highest broad sense heritability exhibited for alkali spreading value $(99.94 \%)$ followed by amylose content $(99.04 \%)$, kernel length after cooking (98.42) and gel consistency (98.33). High heritability values indicate that the characters under study are less influenced by environment in their expression. The plant breeder, therefore adopt simple selection method on the basis of the phenotype of the characters which ultimately improves the genetic background of these traits. Similar results have been reported by Rathi et al. (2010); Babu et al. (2012); Sarawgi et al. (2000), Gannamani (2001) and Sao (2002).

\subsubsection{Genetic advance as percent of mean:}

The estimates of genetic advance as percent of mean provide more reliable information regarding the effectiveness of selection in improving the traits. Genetic advance denotes the improvement in the genotypic value of the new population over the original population. Johnson et al. (1955) categorized the genetic advance as percent of mean as high (>20\%), moderate (10-20\%) and low $(<10 \%)$. All the studied grain quality traits were exhibited high estimate of genetic advance as percent of mean except for hulling percent $(16.10 \%)$ and milling percent $(17.74 \%)$ which showed moderate GA as percent mean. Highest GA as percent mean was exhibited alkali spreading value $(92.84 \%)$ followed by gel consistency $(55.01 \%)$ kernel breadth after cooking (38.83\%) and amylose content $(35.08 \%)$. Similar findings were also reported by Shivani \& Reddy (2000), Iftekharuddaula et al. (2001), Gannamani (2001), Sao (2002), Rathi et al., (2010) and Babu et al. (2012). High heritability with high genetic advance as percent mean was observed for all the grain quality traits except for hulling percent and milling percent which indicated that expression of these traits are less influenced by environment and controlled by additive gene action (Panse, 1957). Therefore, these traits could be improved through direct selection or progeny selections. High heritability with moderate GA as percent mean was observed for trait hulling percent and milling percent which indicate that these trait are also governed by additive gene action and can be improved by selection methods with proper care (Roychowdhury \& Tah, 2011).None of the trait exhibited high heritability with low GA as percent mean which indicate the absence of non-additive gene action among the studied traits.

\subsection{Descriptive Statistics for various grain quality parameters:}

Descriptive statistical measures can reveal a great deal of information about any variable of interest. Descriptive statistics, presenting the measures of central tendency and measure of variations for all the traits are given in table 4 . Brown rice length ranges from $3.65 \mathrm{~mm}$ (Tulsimongra) to $9.10 \mathrm{~mm}$ (DokraDokri) with an average of $5.84 \mathrm{~mm}$ (Figure 1). Brown rice breadth ranges from $1.45 \mathrm{~mm}$ (Chinniparas) to $2.90 \mathrm{~mm}$ (Ranikajar) with an average of $1.96 \mathrm{~mm}$. Brown rice $\mathrm{L} / \mathrm{B}$ ratio ranges from $1.87 \mathrm{~mm}$ (Manki) to $4.21 \mathrm{~mm}$ (Chinniparas) with an average of $3.03 \mathrm{~mm}$. Kernel length ranges from $3.10 \mathrm{~mm}$ (Tulsimongra) to $7.50 \mathrm{~mm}$ (Hathipanjra) with an average of $5.24 \mathrm{~mm}$ (Figure 2). Kernel breadth ranges from $1.40 \mathrm{~mm}$ (Chinniparas) to $2.65 \mathrm{~mm}$ (Bhujanin) with an average of $1.88 \mathrm{~mm}$. Kernel L/B ratio ranges from $1.72 \mathrm{~mm}$ (BhejrimaiDhan) to $3.83 \mathrm{~mm}$ (Jhilli) with an average of $2.84 \mathrm{~mm}$.

Standard evaluation system (SES), IRRI (1996) based grain shape classification of all genotypes are given in table 5. Sixty nine genotypes have short slender type grain characteristics whereas 47 genotypes have short bold type grains (Table 5). Eighty four land races have medium slender type grain characteristics. Out of 215 rice genotypes, 7 genotypes has long slender type grain feature whereas 4 genotypes has long bold type grain characteristics.

Kernel length after cooking ranges from $4.70 \mathrm{~mm}$ (Loktimachi) to $11.25 \mathrm{~mm}$ (Kapri) with an average of $7.58 \mathrm{~mm}$. Kernel breadth after cooking ranges from $1.75 \mathrm{~mm}$ (Bhajna) to $4.32 \mathrm{~mm}$ (Lalbarhasal) with an average of $2.79 \mathrm{~mm}$. Kernel L/B ratio after cooking ranges from $1.09 \mathrm{~mm}$ (Lalbarhasal) to $4.67 \mathrm{~mm}$ (Kabeli) with an average of $2.76 \mathrm{~mm}$. Elongation ratio ranges from 1.14 (Karhani) to 2.18 (Kapri) with an average of 1.45. Kapri showed almost doubled elongation ration which is the basic feature of 
Table 4 Descriptive statistics for grain quality traits in indigenous rice landraces

\begin{tabular}{|c|c|c|c|c|c|c|c|c|c|c|c|c|}
\hline Statistic & Sum & Mean & $\begin{array}{l}\text { Mini } \\
\text { mum }\end{array}$ & $\begin{array}{l}\text { Maxi } \\
\text { mum }\end{array}$ & Range & $\begin{array}{c}1 \mathrm{st} \\
\text { Quartile }\end{array}$ & $\begin{array}{c}\text { Medi } \\
\text { an }\end{array}$ & $\begin{array}{c}\text { 3rd } \\
\text { Quartile }\end{array}$ & $\begin{array}{l}\text { Varianc } \\
\mathrm{e}(\mathrm{n}-1)\end{array}$ & $\begin{array}{l}\text { Standard } \\
\text { deviation } \\
(\mathrm{n}-1)\end{array}$ & $\begin{array}{l}\text { Skewness } \\
\text { (Pearson) }\end{array}$ & $\begin{array}{r}\text { Kurtosis } \\
\text { (Pearson) }\end{array}$ \\
\hline Brown rice length (mm) & 1255.75 & 5.84 & 3.65 & 9.10 & 5.45 & 5.50 & 5.75 & 6.15 & 0.55 & 0.74 & 0.81 & 3.03 \\
\hline $\begin{array}{l}\text { Brown rice bredth } \\
(\mathrm{mm})\end{array}$ & 421.65 & 1.96 & 1.45 & 2.90 & 1.45 & 1.70 & 1.90 & 2.10 & 0.09 & 0.31 & 0.66 & 0.01 \\
\hline Brown rice $L / B$ ratio & 652.26 & 3.03 & 1.87 & 4.21 & 2.34 & 2.74 & 3.08 & 3.34 & 0.21 & 0.46 & -0.19 & -0.04 \\
\hline Kernel length (mm) & 1125.85 & 5.24 & 3.10 & 7.50 & 4.40 & 4.95 & 5.25 & 5.50 & 0.37 & 0.61 & 0.16 & 2.17 \\
\hline Kernel breadth $(\mathrm{mm})$ & 404.05 & 1.88 & 1.40 & 2.65 & 1.25 & 1.65 & 1.85 & 2.05 & 0.08 & 0.28 & 0.56 & -0.13 \\
\hline Kernel L/B ratio & 610.60 & 2.84 & 1.72 & 3.83 & 2.11 & 2.54 & 2.85 & 3.12 & 0.17 & 0.42 & -0.12 & -0.35 \\
\hline $\begin{array}{l}\text { Kernel length after } \\
\text { cooking }(\mathrm{mm})\end{array}$ & 1629.75 & 758 & 4.70 & 11.25 & 6.55 & 6.90 & 7.50 & 8.10 & 1.13 & 1.06 & 0.51 & 0.93 \\
\hline $\begin{array}{l}\text { Kernel breadth after } \\
\text { cooking }(\mathrm{mm})\end{array}$ & 602.55 & 2.80 & 1.75 & 4.32 & 2.57 & 2.40 & 2.70 & 3.10 & 0.30 & 0.55 & 1.92 & 10.74 \\
\hline $\begin{array}{l}\text { Kernel L/B ratio after } \\
\text { cooking }\end{array}$ & 593.98 & 2.76 & 1.09 & 4.67 & 3.58 & 2.47 & 2.76 & 3.02 & 0.19 & 0.44 & 0.21 & 1.48 \\
\hline Elongation ratio & 312.79 & 1.45 & 1.14 & 2.18 & 1.05 & 1.33 & 1.41 & 1.54 & 0.03 & 0.18 & 1.22 & 1.80 \\
\hline Hulling \% & 15971.48 & 74.29 & 44.07 & 88.27 & 44.20 & 71.05 & 75.06 & 78.25 & 41.12 & 6.41 & -0.71 & 1.93 \\
\hline Milling \% & 14084.04 & 65.51 & 43.62 & 77.46 & 33.84 & 62.04 & 66.10 & 70.28 & 36.94 & 6.08 & -0.59 & 0.33 \\
\hline $\mathrm{HRR} \%$ & 12309.76 & 57.25 & 37.78 & 69.79 & 32.01 & 52.48 & 59.30 & 61.74 & 37.66 & 6.14 & -0.57 & -0.31 \\
\hline Alkali Spreading Value & 871.50 & 4.05 & 1.00 & 7.00 & 6.00 & 2.00 & 4.00 & 6.00 & 3.34 & 1.83 & 0.11 & -1.23 \\
\hline GelConsistency & 13134.00 & 61.09 & 29.50 & 98.50 & 69.00 & 46.50 & 61.50 & 69.50 & 272.90 & 16.52 & 0.50 & -0.20 \\
\hline Amylose content $(\%)$ & 5047.69 & 23.48 & 11.84 & 33.82 & 21.98 & 20.48 & 23.88 & 25.71 & 16.22 & 4.03 & -0.09 & 0.23 \\
\hline
\end{tabular}

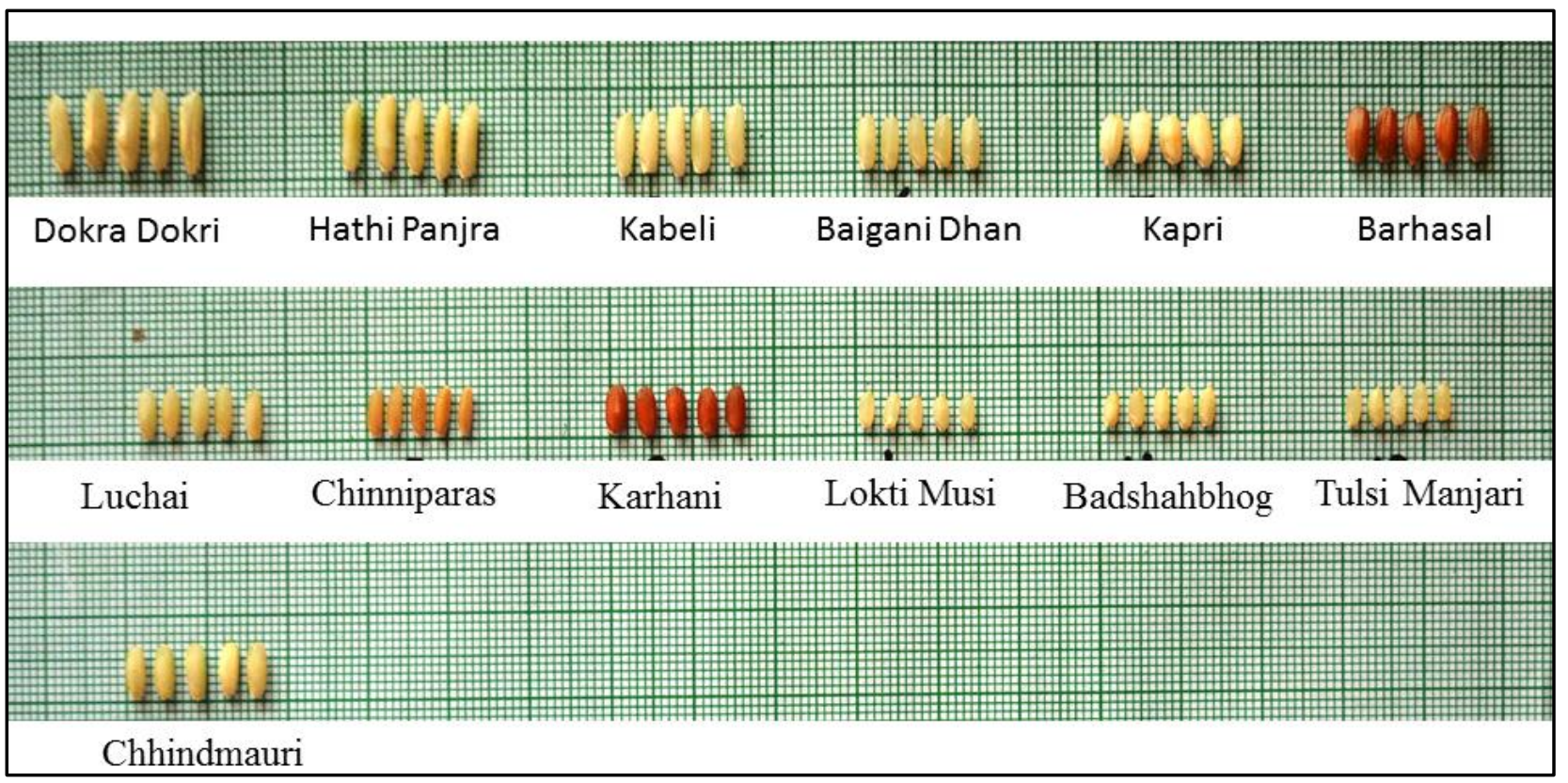

Figure 1 Lengthwise arrangement of hulled rice of identified superior genotypes

Journal of Experimental Biology and Agriculture Science http://www.jebas.org 
Table 5 Classification of 215 indigenous rice landraces based on grain shape (SES, IRRI 1996)

\begin{tabular}{|c|c|c|c|c|}
\hline $\begin{array}{l}\text { Grain } \\
\text { Type }\end{array}$ & $\begin{array}{l}\text { Kernel } \\
\text { length } \\
(\mathrm{mm})\end{array}$ & $\begin{array}{c}\text { Kernel } \\
\mathrm{L} / \mathrm{B} \\
\text { ratio }\end{array}$ & Genotypes & Total \\
\hline $\begin{array}{l}\text { Short } \\
\text { slender }\end{array}$ & $<6.0$ & $>3.0$ & $\begin{array}{l}\text { Jhilli, Hajan, Kosawari, HarunaMasri, ChatiyaNakhi, ChinniParas, B.D. Safri-2, Sonagathi-2, Mota } \\
\text { Safri-2, JhimiprasSamlayi, Sonkharcha, MotaChudi, Bashabhog, Bhajna, MotaSafri, Safri, } \\
\text { Khetganga, Bhusu, Antarved, Ratajhinga, Bhadvel, Sawani, KharikhaKuchi, Pancho, Kherkakuchi, } \\
\text { Indjopa, Brown Rice-2, MatkoDhan, Badshabhog Selection-1, BhataNakhi, Ikkopatla, } \\
\text { DeshiSurmatiya, Ramshri, Pataniyajhuli, DhauraMundariya, Anjaniya, Ankapalli, Dubraj, } \\
\text { MohlaiBanko, Agyasal, Ramjhilli, SatraSafri, Ikkomota, Safri-2, Sichar, Dowana, Nanded, } \\
\text { NimaliyaBanki, Brown Rice-1, Pratiksha, BaktiChudi, SutaiDhan, Lajini Super, Jhimipras, Katrani- } \\
\text { 4, Badshabhog-2, RuchiDhan, Dubraj, Jhimipras-2, Jela, Kalinga, Bhata Masri-2, Dhaniyaphool, } \\
\text { Bhusu, Sanchorma, Hardigathi, Danwar, Rang Chudi, Jonyaphool }\end{array}$ & 69 \\
\hline $\begin{array}{l}\text { Short } \\
\text { bold }\end{array}$ & $<6.0$ & $<2.5$ & $\begin{array}{l}\text { LalmaDhan, Ramlaxman, Haripanti, Kanakbans, Korma, DRRH-3, Barhasal, Sugandha, Dandrice, } \\
\text { Petgadi, Barhasal-2, Anjani, Nariyalphool, Surmatiya, DhauraMundariya, Dadbanko, Sadachar, } \\
\text { SuaPankhi, Kalajeera, NariyalJhoba, Loindi, Barhani, Bhaisapuchhi, Lochai, PivriLochai, Sindursal, } \\
\text { KareniDhan, Santio, RatanChudi, LoktiMusi, Agni Fag, Mahabaikoni, Ramlichonch, HathiPinjara, } \\
\text { Tulsimongra, Rani Kajar, Panwar, Govardhan Kali Kamod 2, Jana Dhan, Sonagathi, Bhujnin, } \\
\text { Modipeera, Chhindmauri, Mala Gauri, Manki, Muni Bhog, BhejrimaiDhan }\end{array}$ & 47 \\
\hline $\begin{array}{l}\text { Medium } \\
\text { slender }\end{array}$ & $<6.0$ & $\begin{array}{l}2.5- \\
3.0\end{array}$ & $\begin{array}{l}\text { BahalBinjo, PhalodDhan, Ramigauri, KondhaKoya, Kanchan, GudkamalDhan, Kapri, Byalo, } \\
\text { Chhindmauri, Ramlaxman, Masri, Gaurimala, Jalkeshar, Gatuvan, Majori, Katrani-7, Laxmibhog, } \\
\text { Byalo, Bhusi, Gangabaru, Arokhutu, Kadamphool, Kumhdayin, Danighoda, Barhasal-3, } \\
\text { Bhunduluchai, Kabeli, Rajabangla, Safri-17, BaigaSeeng, Badshabhog, Bodibaja, Rudra, Parra } \\
\text { Dhan, Godadani, Baikoni, Mayath, Alsenga, RelaDhan, Tulsibhog, TulsiManjari, Jonyaphool, Asam } \\
\text { Chudi-3, BhathaMasri, B.D. Safri, GadurSela, BeedelaDhan, TuriyaKhudig, PangudiGoindi, } \\
\text { Jhingapuchhi, BaiganiDhan, BansveeraDhan, Ranikajal, MemriKhedi, Bansgathi, Khajoor, } \\
\text { Maidubraj, Kari Alcha, Sihar, Jalsinga, Kari Grass, Asam Chudi-2, Luchai, Nandel, Jhunuprash, } \\
\text { Chhindmauri, Jauphool, Sudama, Karhani, Manmohan, Kanakbhog, AsamChudi, OdhaDhanBanarsi, } \\
\text { Tulsi Mala, Katrani-9, Samarlengda, Lalapana, ParwatKal, HR 14-1 Heera, Bathrash, ChurlaiBanko, } \\
\text { MaranDhan, Luchai-2, Gomti, Lalbarhasal, Karhani, Mejhri, Saraitoliha }\end{array}$ & 88 \\
\hline $\begin{array}{l}\text { Long } \\
\text { slender }\end{array}$ & $>6.0$ & $>3.0$ & HathiPanjra, Raja Banga, Mahamaya, DokraDokri, Rajeshwari, Gangachur, JhilliSafri & 7 \\
\hline \multirow[t]{2}{*}{$\begin{array}{l}\text { Long } \\
\text { bold }\end{array}$} & $>6.0$ & $<3.0$ & Kari Gilash, Rani Parewa, Jhoomar, Jalgundi & 4 \\
\hline & & & Total & 215 \\
\hline
\end{tabular}

basmati rice. So it can be said that Kapri rice landrace has basmati type feature (Figure 3).

Hulling percent ranges from $44.07 \%$ (Reladhan) to $88.27 \%$ (Luchai) with an average of $74.29 \%$. Total 30 genotypes showed $>80 \%$ hulling percent among the all genotypes. Milling percent ranges from $43.62 \%$ (Reladhan) to $77.46 \%$ (BaigniDhan) with an average of $65.51 \%$.Total 56 genotypes showed $>70 \%$ milling percent out of 215 genotypes. High head rice yield is one of the most important criteria for measuring milled rice quality. Head rice recovery percent ranges from $37.78 \%$ (Reladhan) to $69.79 \%$ (Badshahbhog 2) with an average of $57.25 \%$. Total 14 genotypes showed $>65 \%$ head rice recovery percent among all the genotypes. Genotypes having high hulling percent, miliing percent and HRR percent could be utilized for development of good quality rice variety.

Gelatinization temperature (GT) is a measure of temperature and time required for cooking of rice grains which is estimated based on alkali spreading value (ASV). The ASV varied over a wide range from 1 to 7 (Figure 4).Total 69 genotypes have intermediate type alkali spreading value (4-5 scale) which has $70-74^{\circ} \mathrm{C}$ gelatinization temperature. Total 55 genotypes showed high ASV (6-7) which had low gelatinization temperature. Remaining 91 genotype showed high $\left(>74{ }^{0} \mathrm{C}\right.$ gelatinization temperature $)$.

Landrace Luchai $(29.25 \mathrm{~mm})$ had lowest gel consistency whereas landraces Odhadhan had highest $(98.50 \mathrm{~mm})$ gel consistency with an average of $61.09 \mathrm{~mm}$ (Figure 5). Gel consistency determines the softness or hardness of cooked rice. Soft and medium gel 


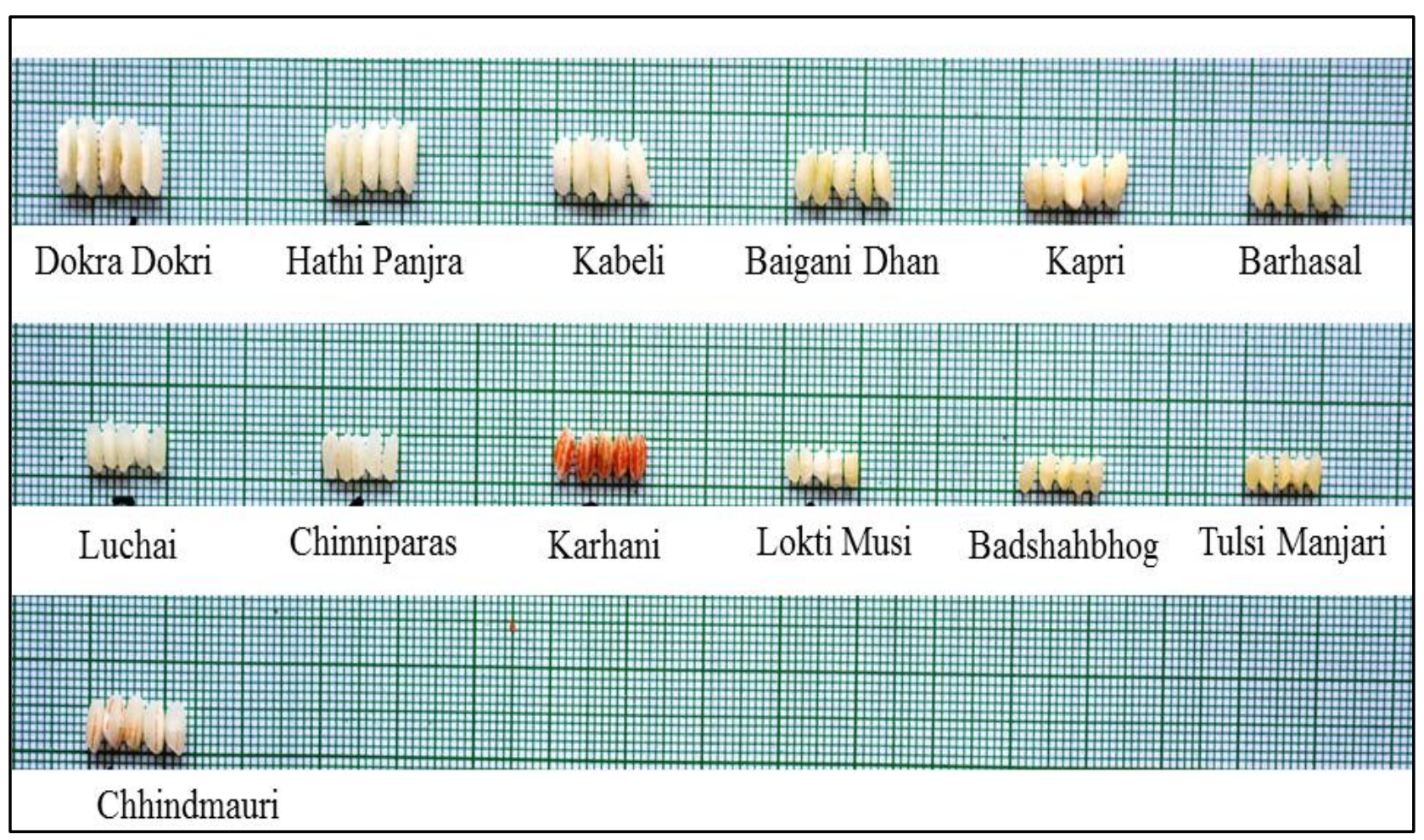

Figure 2 Lengthwise arrangement of milled rice of identified superior genotypes

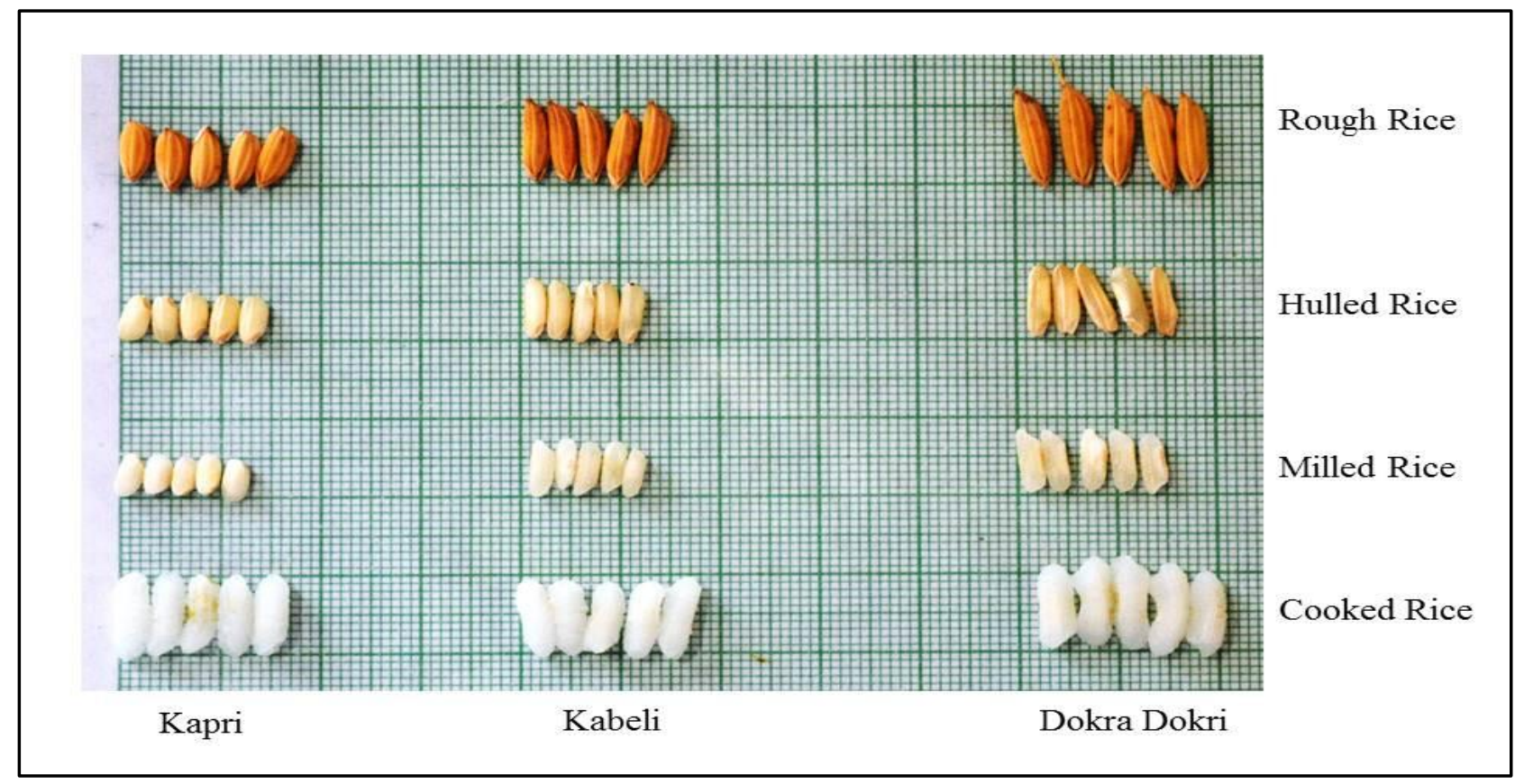

Figure 3 Basmati property of landrace Kapri

Journal of Experimental Biology and Agriculture Science http://www.jebas.org 


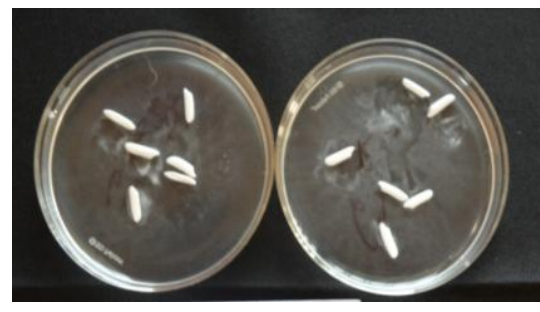

1. Kernel not affected

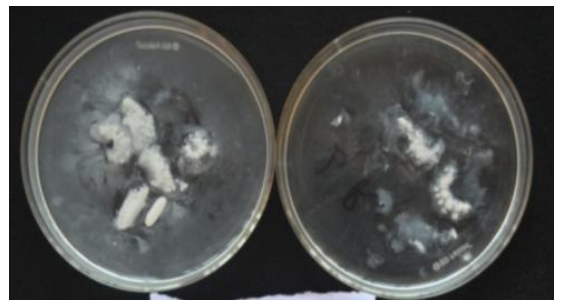

5. Kernel split or segmented, collar complete and wide

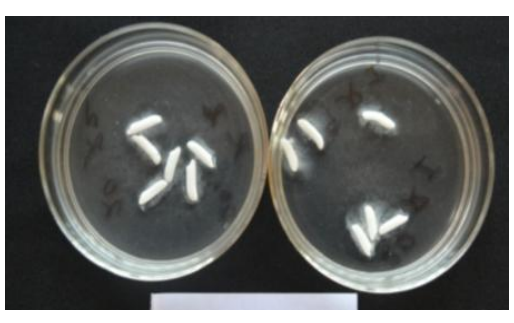

2. Kernel Swollen

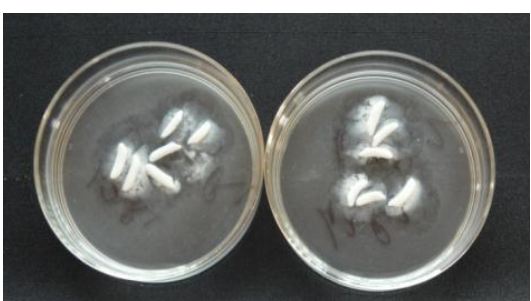

4. Kernel swollen, collar complete and wide

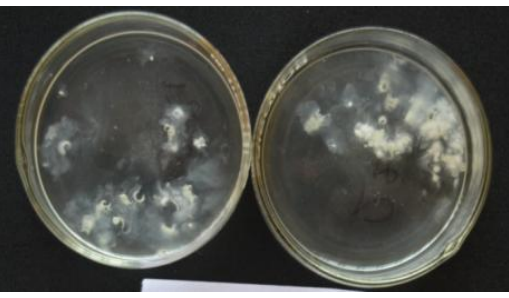

7. All kernel dispersed and inter mingled

Figure 4 Representation of alkali spreading value (ASV) in rice landraces

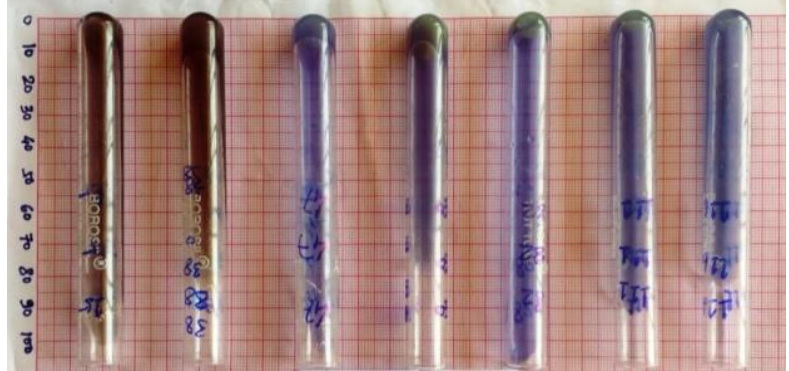

Soft gel consistency (61-99 mm)

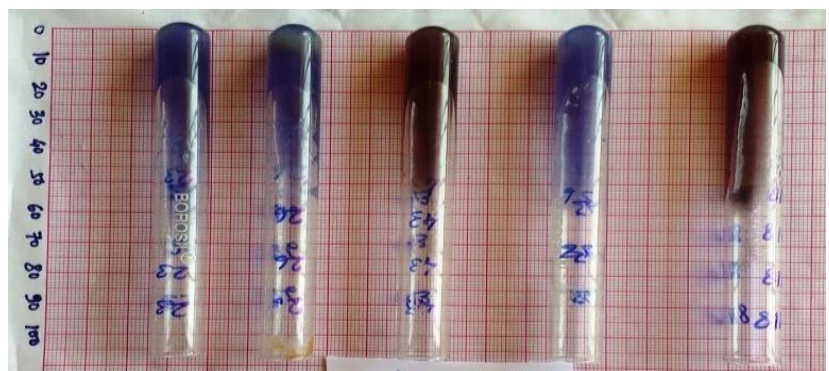

Medium gel consistency (41-60 mm)

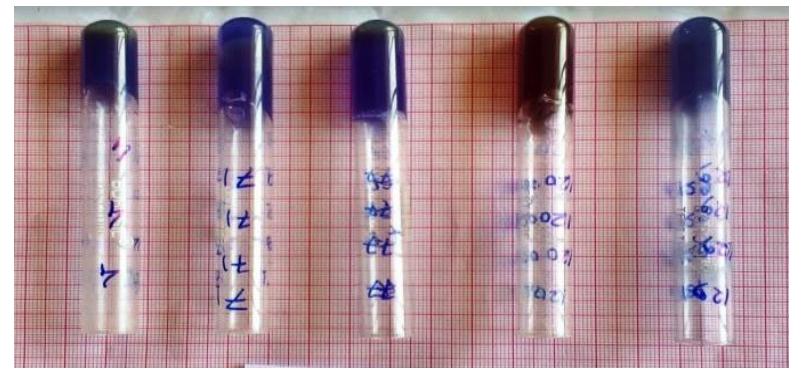

Hard gel consistency $(25-40 \mathrm{~mm})$

Figure 5 Representation of gel consistency scales in rice

Journal of Experimental Biology and Agriculture Science 


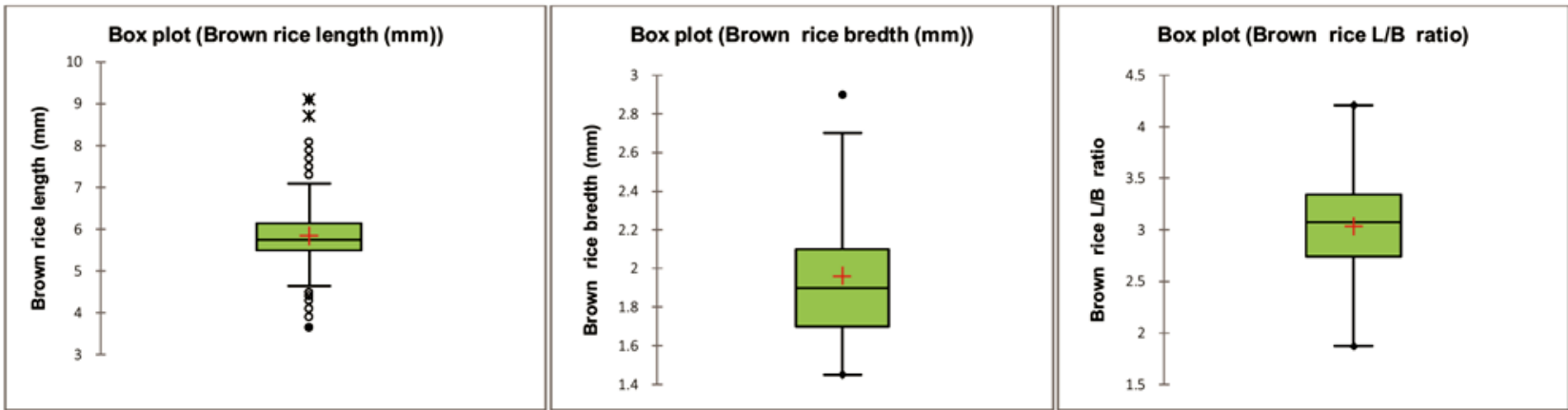

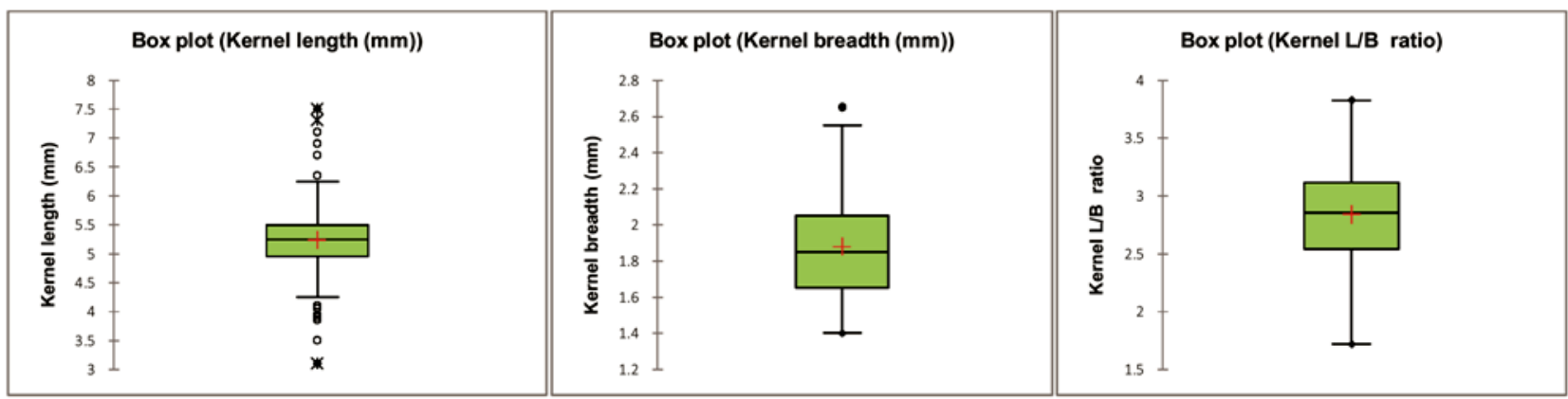

Symbols: --- Median + Mean $\quad$ Minimum/ Maximum Outliers 2

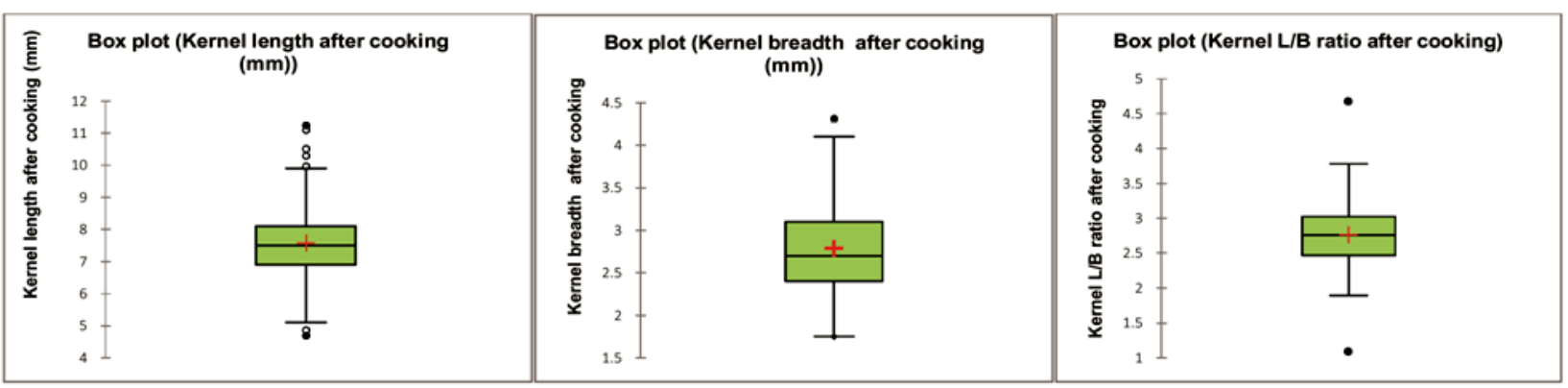

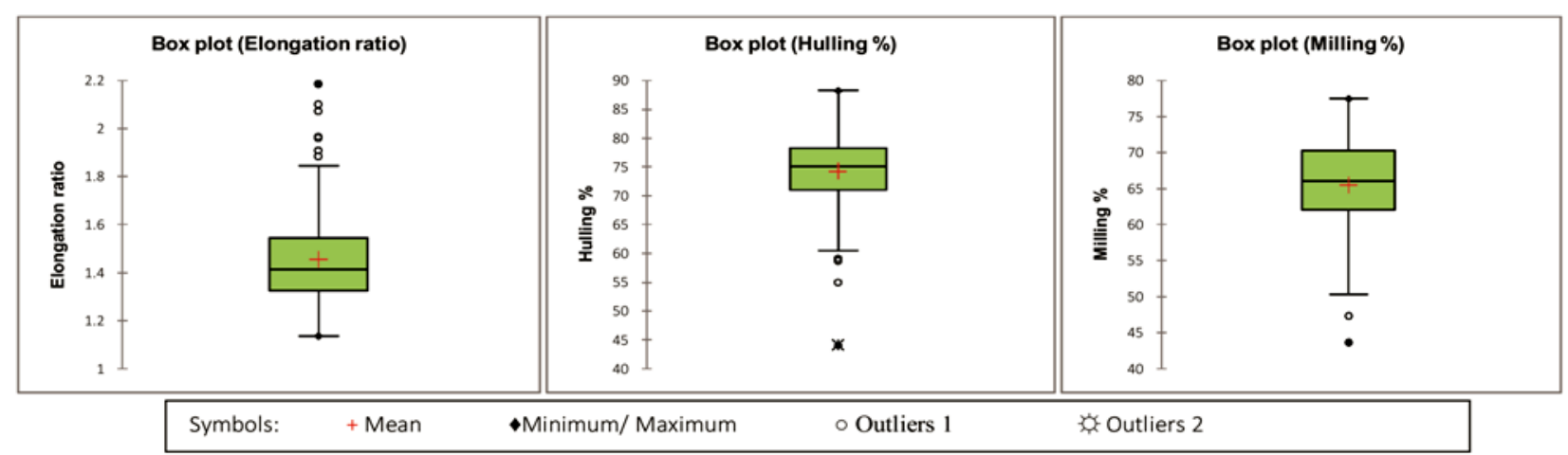

Journal of Experimental Biology and Agriculture Science http://www.jebas.org 


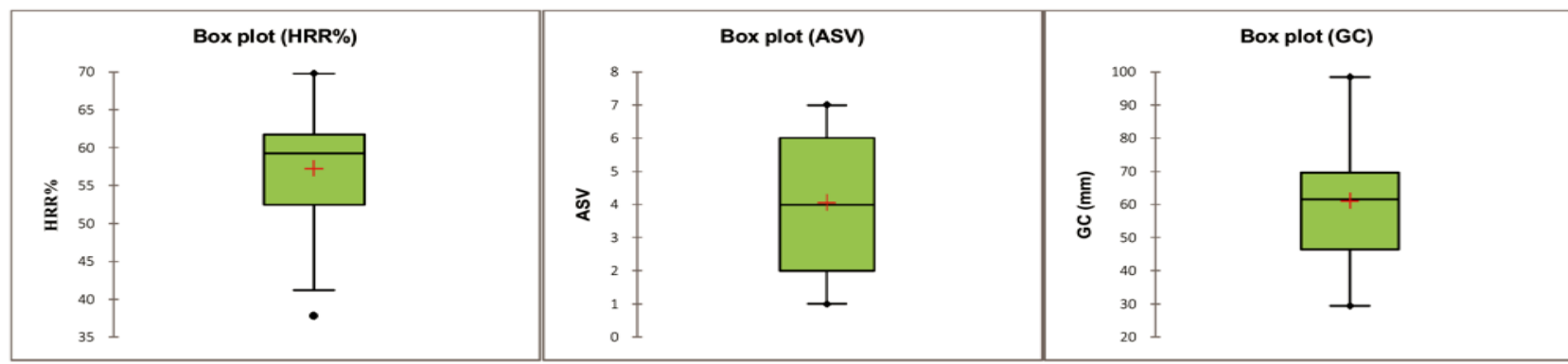

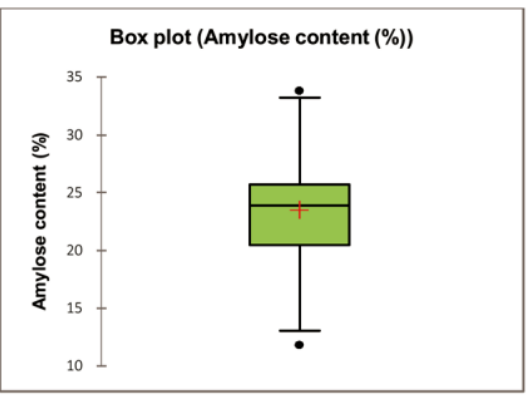

Figure 6 Boxplots showing descriptive statistics of various grain quality traits in indigenous rice landraces

Sumhols: + Mean $\quad$ Minimum/ Maximum o Outliers $1 \quad$ ión Outliers ?

Figure 6 Boxplots showing descriptive statistics of various grain quality traits in indigenous rice landraces

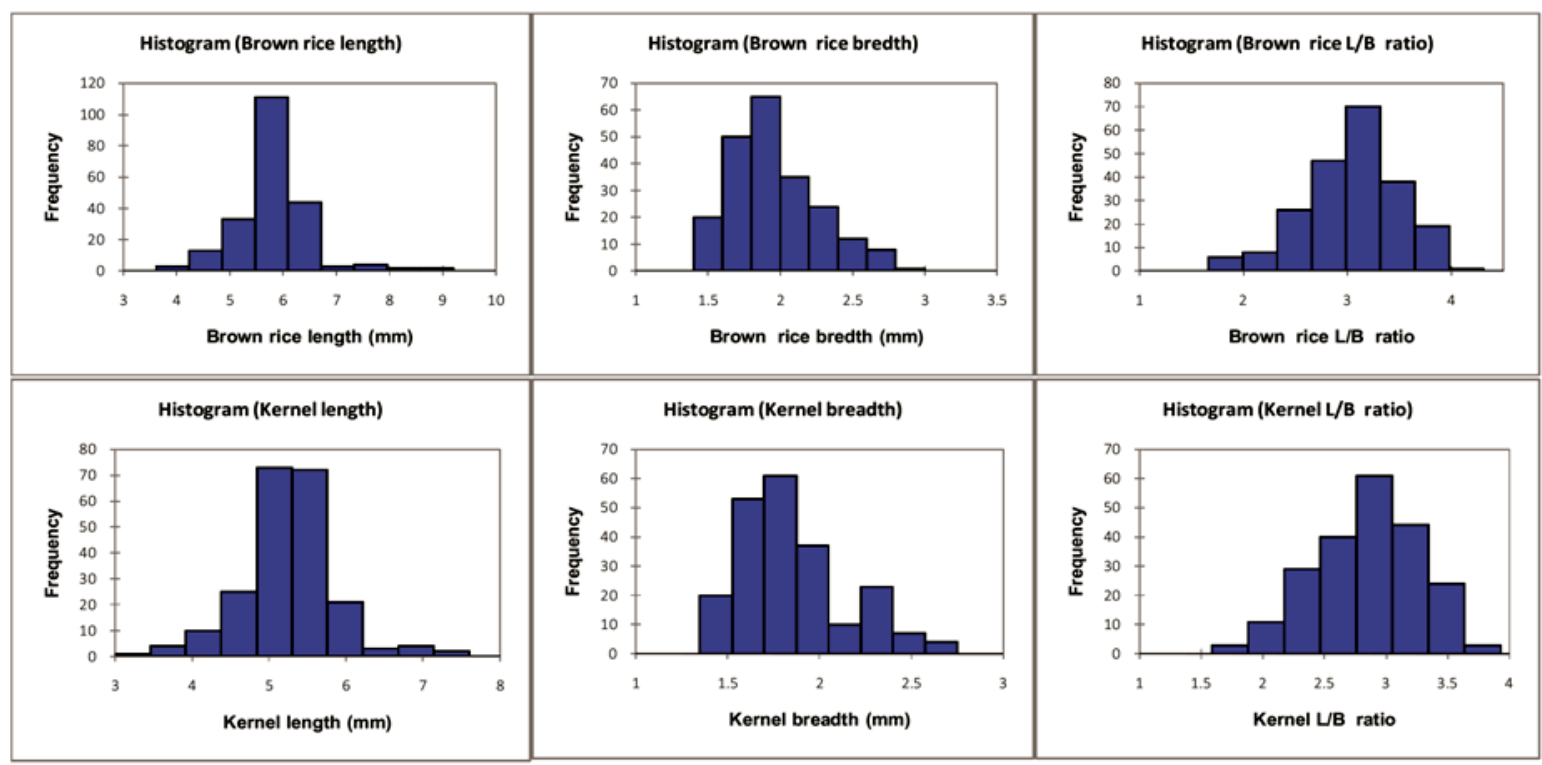

Journal of Experimental Biology and Agriculture Science http://www.jebas.org 

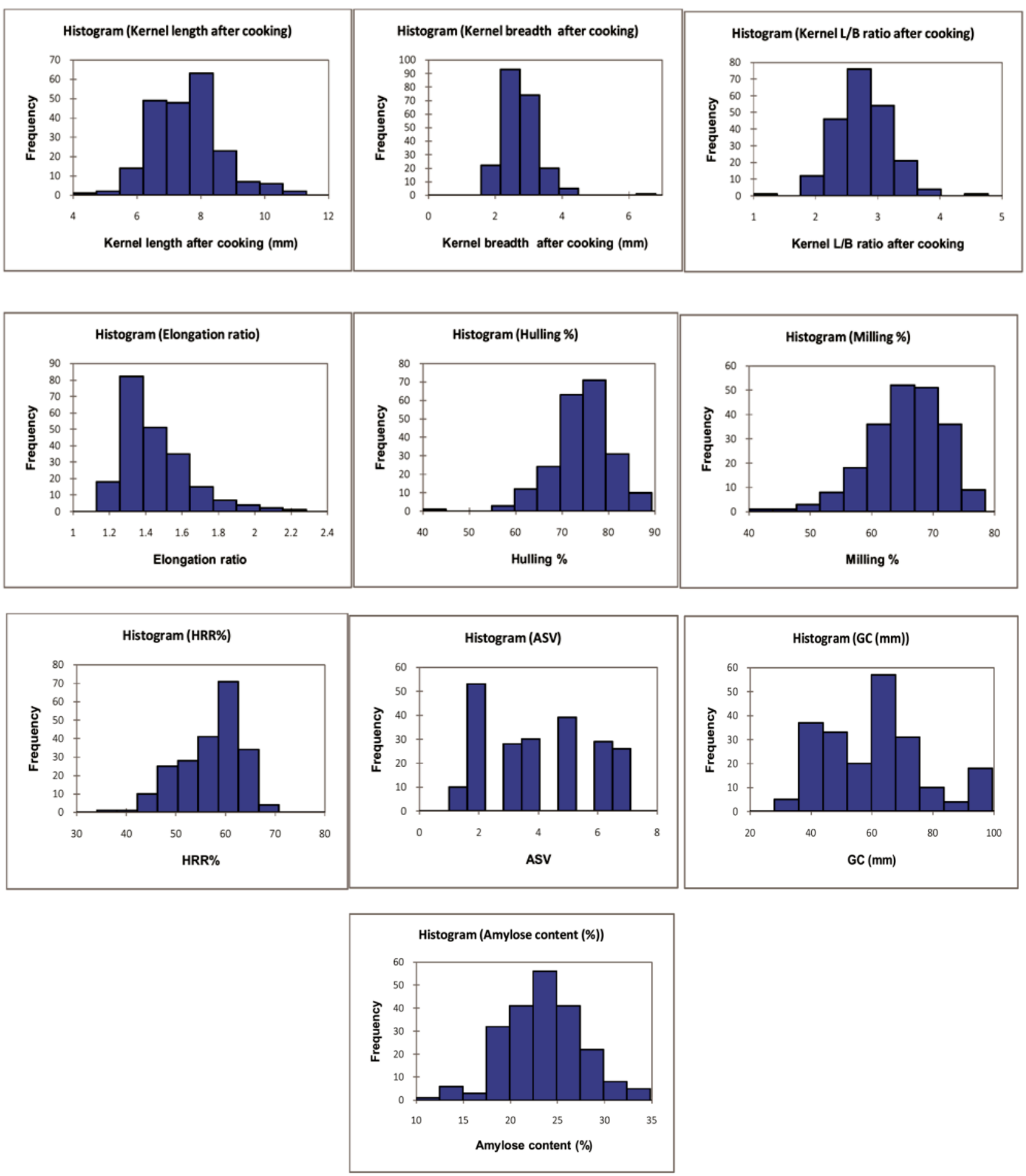

Figure 7 Histogram showing frequency distribution of various grain quality traits in indigenous rice landraces 
consistency types are generally preferred by consumers at different regions. In present investigation, total 81 genotypes had intermediate type $(40 \mathrm{~mm}-60 \mathrm{~mm})$ gel consistency. Amylose content is considered as a prime determinant of cooking quality with GT and GC in rice. The amount of amylose determines how sticky the rice grain will be when cooked. Amylose content ranges from $11.84 \%$ (Dadbanko) to $33.82 \%$ (Bhatamasri) with an average of $23.48 \%$.Total 100 genotypes has intermediate amylose content (20-25\%). Varieties with intermediate amylose content are generally most preferred in Indian conditions because they look dry and fluffy retaining their soft texture even after cooling.

Among the traits, highest standard deviation was found for gel consistency followed by hulling percent, milling percent and head rice recovery percent. Standard deviation provides a reliable estimate of the degree to which the numbers in the variable deviate from the mean. Thus, the standard deviation is truly a standard measure of variability that applies to any distribution, regardless of the unit of measure used (Larson \& Farber, 2002). If the standard deviation is very small, scores are not scattered far from the mean. The larger the standard deviation, the more widely scattered are values in the distribution (McHugh, 2003).

\subsection{Box plots profile based on descriptive statistics}

Descriptive statistics based box plots for each trait has been given in Figure 6 which showed graphical summary of the distribution of a trait. Median value of each trait is almost similar or nearer to their respective mean value which indicated the proper distribution of genotypes for corresponding traits. Box plot showed that among the 218 genotypes, $75 \%$ individuals have equal to or less than $78.25 \%$ (Third quartile) hulling percent while $25 \%$ genotypes have equal to or less than $71.05 \%$ (First quartile) hulling percent. In the same way, $75 \%$ genotypes have equal to or less than $70.28 \%$ milling percent while $25 \%$ genotypes have equal to or less than $62.04 \%$ milling percent. Similarly, $75 \%$ genotypes have equal to or less than $61.74 \%$ (Third quartile) head rice recovery percent while $25 \%$ genotypes have equal to or less than $52.48 \%$ (First quartile)head rice recovery percent. This showed that higher hulling percent, milling percent and HRR \% were observed in more than or equal to $75 \%$ genotypes. For amylose content, $75 \%$ genotypes have equal to or less than $25.71 \%$ (Third quartile) amylose whereas $25 \%$ genotypes have equal to or less than 20.48 (First quartile). Upper and lower outliers of each trait are the indicative of maximum and minimum values for the corresponding trait which are presented in corresponding box plots.

\subsection{Frequency distribution based histogram of grain quality} traits

Histogram showing frequency distribution for various grain quality traits on 215rice genotypes revealed different patterns of distribution as shown in Figure 7. Histogram showed that none of the trait follows the exact normal distribution pattern but brown rice length, kernel length, kernel L/B ratio, kernel L/B ratio after cooking and amylose content showed somehow similar to normal distribution. The study on frequency distribution of traits using skewness and kurtosis helps to extract the available information on nature of gene action (Fisher et al., 1932) and number of genes controlling the traits (Robson, 1956), respectively. Skewness and kurtosis for all studied traits are given in Table 4. Skewness values and histogram for brown rice L/B ratio (-0.19), kernel L/B ratio (-0.12), hulling percent (-0.71), milling percent (-0.59), head rice recovery percent $(-0.57)$ and amylose content $(-0.09)$ showed that these traits were negatively skewed. Whereas, brown rice length (0.81), brown rice breadth (0.66), kernel length (0.16), kernel breadth (0.56), kernel length after cooking (0.51), kernel breadth after cooking (0.52), elongation ratio (1.22), alkali spreading value $(0.11)$ and gel consistency $(0.50)$ were positively skewed.

The skewed distribution of a trait in general suggests that the trait is under the control of non-additive gene action and is influenced by environmental variables. Positive skewness is associated with complementary gene interactions while negative skewness is associated with duplicate (additive $\mathrm{x}$ additive) gene interactions. The genes controlling the trait with skewed distribution tend to be predominantly dominant irrespective of whether they have increasing or decreasing effect on the trait (Pooni et al., 1977). In this study, all the grain quality traits showed minor skewnessas the value of skewness for all the traits were close to zero (Table 1). So it can be said that non-additive gene action is absent in studied traits which is also confirmed by variability parameter studies.

Kurtosis values for brown rice L/B ratio (-0.04), kernel breadth ($0.13)$, kernel L/B ratio (-0.35), kernel breadth after cooking ($0.06)$, head rice recovery percent $(-0.31)$, ASV (-1.23) and gel consistency $(-0.20)$ showed that these traits were negatively skewed. Whereas, brown rice length (3.03), brown rice breadth (0.01), kernel length (2.17), kernel length after cooking (0.93), kernel L/B ratio after cooking (1.48), elongation ratio (1.80), hulling percent (1.93), milling percent (0.33) and amylose content (0.23) were positively skewed. Histogram showed that kernel L/B ratio, kernel breadth after cooking, kernel L/B ratio after cooking, hulling percent, milling percent and amylose content showed similar to mesokurtic configuration whereas rest of the trait showed leptokutic configurations. None of the trait showed platykurtic configuration. The traits with leptokurtic and 
platykurtic distribution are controlled by fewer and more number of genes, respectively. Kurtosis is negative or close to zero in the absence of gene interaction and is positive in the presence of gene interactions (Nachimuthu et al., 2014).

\section{Conclusion}

The study revealed that there was significant genetic variability among the genotypes for all the grain quality characters examined in the landraces and genotypes of rice. Several land races were identified for good grain quality features which could be used in rice breeding strategy and biotechnological research for further yield and quality characters improvement. Land races viz. Tulsimanjari, Luchai, BaiganiDhan, Kapri, and Badshahbhog have been identified superior and desirable from this study. TulsiMongra has shortest kernel length whereas HathiPanjra and DokraDokrahave longest kernel length. Other land races viz.Luchai, BaiganiDhan and Badshahbhog were identified superior for good milling parameters. Kapri, Bhajna and Kabeli were identified superior for cooking quality parameters in which Kapri showed Basmati type quality (2.18 length wise elongation after cooking). All the genetic parameters for studied traits showed less influence of environment which is good for further selection of these traits. It can be concluded that indigenous rice landraces enriched in cooking and eating quality features hold enormous potential to be utilized as value added products. The present investigation provided the breeding materials to the rice breeders for exploitation of landraces in future breeding programme. Some important traits like hulling percent, milling percent, head rice recovery, amylose content, gelatinization temperature and elongation ratio can be significantly improved by exploiting the landraces of rice

\section{Acknowledgement}

This research was the part of a Ph.D. programme supported by Inspire fellowship (awarded to PKS), Department of Science and Technology, Government of India, New Delhi. We are thankful toDr. A. K. Sarawgi, Head, Department of Genetics and Plant Breeding, IGKV, Raipur for their kind support and help during this experiment and academic programme.

\section{Conflict of Interest}

Authors declare that there is no conflict of interests arising from this study.

\section{References}

Babu VR, Shreya K, Dangi KS, Usharani G, Nagesh P (2012) Genetic variability studies for qualitative and quantitative traits in popular rice (Oryza sativa L.) hybrids of India. International Journal of Scientific and Research Publications 2: 1-5.
Bellon M, Pham J, Jackson M (1997) Genetic conservation: A role for rice farmers. In: Maxted N, Ford- Lloyd B, Hawkes J (Eds.), Plant Genetic Conservation: The in situ Approach; Chapman and Hall: London, UK. Pp. 263-289.

Burton GW (1952) Quantitative inheritance in grasses. 6th International Grassland Congress 1:277-283.

Burton GW, Devane EH (1952) Estimating heritability in tall fescue (Festuca arundinaceae) from replicated clonal material. Agronomy Journal 45: 478-481.

Chaudhary PK, Singh RP (1994) Genetic variability, correlation and path analysis of yield components of rice. Madras Agricultural Journal 81:468-470.

Devi KR, Chandra SB, Lingaiah N, Hari Y, Venkanna V (2017) Analysis of variability, correlation and path coefficient studies for yield and quality traits in rice (Oryza sativaL.). Agriculture Science Digest 37(1): 1-9.

Devi KR, Parimala K, Venkanna V, Lingaiah N, Hari Y,Chandra SB (2016) Estimation of variability for grain yield and quality traits in rice (Oryza sativaL.). International Journal of Pure and Applied Biosciences 4(2): 250-255.

Dhanwani RK, Sarawagi AK, Solanki A, Tiwari JK (2013) Genetic variability analysis for various yield attributing and quality traits in rice (Oryza sativaL.). The Bioscan 8(4): 14031407.

DRR (2014) Laboratory manual on rice grain quality. Manual of ICAR-DRR, Rajendranagar, Hyderabad.

Fisher RA, Immer FR, Tedin O (1932) The genetical interpretation of statistics of the third degree in the study of quantitative inheritance. Genetics 17:107 -24.

Gannamani N (2001) Study of heterosis and combining ability by utilizing cytoplasmic genetic male sterility and fertility restoration system in rice (Oryza sativa L.), M. Sc. (Ag.) Thesis submitted to the IGAU, Raipur.

Hanson WD, Robinson HF, Comstock RE (1956) Biometrical studies of yield in segregating population Korean Lespandeza. Agronomy Journal 48: 268-272.

Hossain MS, Singh AK, Fasih-uz-Zamann (2009) Cooking and eating characteristics of some newly identified inter sub-specific (indica/japonica) rice hybrids. Science Asia 35: 320-325.

Iftekharuddaula KM, Hassan MS, Islam MJ, Badshah MA, Islam MR, Akhter K (2001) Genetic evaluation and selection criteria of 
hybrids rice in irrigated ecosystem of Bangladesh. Pakistan Journal of Biological Sciences 4: 790-792.

IRRI (1996) Standard evaluation system for rice.4th Edition, IRRI Philippines p52.

Johnson HW, Robinson HF, Comstock RE (1955) Estimation of genetic and environmental variability in soybean. Agronomy Journal 47: 314-318.

Juliano BO (1971) A simplified assay for milled rice amylose. Cereal Science Today 16: 334-340.

Juliano BO, Perez CM (1984) Result of a collaborative test on the measurement of grain elongation of milled rice during cooking. Journal of Cereal Sciences 2: 281-292.

Karuppaiyan R, Kapoor C, Gopi R (2013) Variability, heritability and genetic divergence in lowland rice genotypes under the midhills of Sikkim. Oryza $50: 81-84$.

Kumar MS (1989) Genetic analysis of height and cooking quality traits in basmati rice. IARI, New Delhi.

Kumbhar SD, Kulwal PL, Patil JV, Sarawate CD, Gaikwad AP, Jadhav AS (2015) Genetic Diversity and Population Structure in Landraces and Improved Rice Varieties from India. Rice Science 22: 99:107.

Larson R, Farber B (2002) Elementary statistics: Picturing the world (2nd ed.). Upper Saddle River, NJ: Prentice Hall.

Little RR, Hilder GB, Dawson EH (1958) Differential effect of dilute alkali on 25 varieties of milled white rice. Cereal Chemistry 35: 111-126.

Maneerattanarungroj $\mathrm{P}$, Jermklang $\mathrm{P}$, Kongsook $\mathrm{B}$, Maneerattanarungroj P (2015) Diversity of Grains of Rice Landraces of Northeastern Thailand. International Journal of Chemical, Environmental \& Biological Sciences 3: 317-321.

McHugh ML (2003) Descriptive Statistics, Part II: Most commonly used descriptive statistics. Journal for Specialists in Pediatric Nursing 8: 111-116.

Nachimuthu VV, Robin S, Sudhakar D, Raveendran M, Rajeswari
S, Manonmani S (2014) Evaluation of rice genetic diversity and variability in a population panel by principal component analysis. Indian Journal of Science and Technology 7: 1555-1562.

Panse VG (1957) Genetics of quantitative characters in relation to plant breeding. Indian Journal of Genetics 17: 318-328.

Panse VG, Sukhatme PV (1967) Statistical methods for agricultural workers (2nd Ed) ICAR publications, New Delhi, India.

Pathak PK, Sharma KK (1996) Variability and correlation among physical quality characters of Joha rice of Assam. Journal of Agricultural Science Society North-East India 9:18- 22.

Pooni HS, Jinks JL, Cornis MA (1977) The causes and consequences of non-normality in predicting the properties of recombinant inbred lines. Heredity 38:329-338.

Rabara RC, Ferrer MC, Diaz CL, Cristina M, Newingham V, Romero GO (2014) Phenotypic diversity of farmers' traditional rice varieties in the Philippines. Agronomy 4: 217-241.

Rathi S, Yadav RNS, Sarma RN (2010) Variability in Grain Quality Characters of Upland Rice of Assam, India. Rice Science 17: 330-333.

Robson DS (1956) Application of $\mathrm{K}_{4}$ statistics to genetic variance component analysis. Biometrics 12:433-444.

Roychowdhury R, Tah J (2011) Evaluation of genetic parameters for agro-metrical characters in Carnation genotypes. African Crop Science Journal 19: 183-188.

Sao A (2002) Studies on combining ability and heterosis in $F_{1}$ rice hybrids using cytoplasmic male sterile lines. M. Sc. (Ag.) Thesis submitted to the IGAU, Raipur.

Sarawgi AK, Rastogi NK, Soni DK (2000) Studies on some quality parameters of indigenous rice in Madhya Pradesh. Annuals of Agricultural Research 21: 258-261.

Shivani D, Reddy N (2000) Variability, heritability and genetic advance for morphological and physiological traits in certain rice hybrids. Oryza 37:231-233. 